\title{
Types of Main Administrative Penalties in the Republic of Latvia
}

\author{
Dilshad Salimova \\ Baltic International Academy, Latvia \\ salimovadilshad@gmail.com
}

\begin{abstract}
The purpose of this article is to identify problems arising in the system of administrative penalties. The paper analyses the changes in the Latvian Code of Administrative Offenses. In compiling of the article, legal literature, European and national regulations were studied.

Keywords: changes, Latvian Administrative Offenses Code, offense, punishments.

\section{Introduction}

The purpose of the article is to provide an overview of issues regarding problems in the system of administrative punishments, consider general positions of the main types of penalties, namely, fine, administrative arrest, and confiscation of the subject of an item of an administrative offense, and examine their characteristics.
\end{abstract}

\section{Aim}

The aim of the article is to examine theoretical and practical aspects of administrative penalties, consider positions of Latvian scientists, study the draft law on the adoption of a new administrative code, find a solution and make suggestions for the above issues.

\section{Materials and Methods}

Systematic, statistical, analytical and grammatical methods were used in compiling of the article. 


\section{Results and Discussion}

Recently, a number of disputes have arisen about the ineffectiveness of the current Latvian Administrative Offenses Code (LAoC). The point of disagreement regards legal elements from the Soviet legal system being inherited in the Latvian Code of Administrative Offenses [11]. Since the entry of Latvia into the European Union, national legislation is expected to consider general rules that are specific for the European Union member states.

In connection with the arising problems, the legislator has found only one solution, the adoption of a new code in the future. With this end in view, new concepts of the development of administrative penalties have been created. For developing a new concept and draft law, a number of significant problems have been identified in the legal structure of administrative responsibility. To achieve this, a broader explanation and discussion is required. In this regard, international seminars have been held in Saeima, foreign experts within the field have been invited. Moreover, many Latvian scientists have performed analysis and put forward their decisions on resolving issues in the system of administrative punishments, committing administrative violations and imposition of administrative sanctions.

The reason for the creation of the new code was a number of problems that had accumulated over the years. The Latvian Administrative Offenses Code has been changed over 150 times [10]. Despite the huge number of amendments, there are still multiple elements that are not important for a democratic country. It is believed that the code has inherited a number of legal elements from the Soviet legal system. Some of the legal rules contained in the Code are contradictory and logically unfounded.

The paralegal at the Ministry of Justice of the Republic of Latvia Inessa Kahanovich emphasises: "A number of significant problems were identified in the legal structure of administrative responsibility; this should be considered for developing a new concept of the draft law. Solving these problems requires a broader explanation and discussion in legal circles".

Currently, the draft law has been approved by the Saeima in the second reading, and the law is expected to come into force on January 1,2020. According to the legislator, this reform is aimed at creating a new, clear, fast and effective administrative code.

This article examines the types of main penalties, specifically, administrative arrest, confiscation of the subject of an item of an administrative offense and the establishment of minimum and maximum fines under the draft law.

On July 1, 1985, the Latvian Administrative Offenses Code entered into force, which defines administrative penalties in Chapter 3. The legal definition of administrative penalties is set out in Article 22 of the LAoC, according to which administrative punishment is a measure of responsibility, which is used to educate the offender, in the spirit of observance of laws, rules of respect for the rights and legitimate interests of citizens, society and the state $[2,9]$.

Types of administrative penalties are regulated in Article 23 of the LAoC. 
In practice, the predominant type of administrative penalties are fines (Article 26 of the LAoC) $[13,12]$. The Code establishes minimum and maximum penalties; however, the effectiveness of this type of penalty can be observed in practice.

The practical aspects of the main administrative penalties can be observed in the statistics of the Latvian State Police - "Review on the Status of Juvenile Delinquency, Children, for 12 months of 2017". In this review, Chapter 3 is devoted to the tendency and dynamics of administrative violations. The number of registered administrative violations was 5425 for 2016 and 6266 for 2017. The listed articles, according to statistics, are part 4 of Article 421, parts 1 and 2 of Article 46, Article 167, parts 1 and 2 of Article 1672, parts 1 and 2 of Article 171, parts 1 and 2 of Article 171 ${ }^{1}$, parts 1 and 2 of Article 171 ${ }^{2}$, Article $171^{4}$, parts 1 and 2 of Article 175, Article 110.

In the 12 months of 2017, the number of youth who committed administrative violations increased by 4,400 people, which is 1,296 more than in the previous period. The number of youth for whom protocols of administrative violations were compiling is 3104 for 2016 and 4400 for 2017 [6].

According to the weekly statistics, in Daugavpils district from February 11 to 17, 2018, in total 375 administrative protocols were drawn up, of which three for disorderly conduct, 52 for being in a public place under the influence of alcohol. 16 road accidents were registered where a man was injured in one of them. For violation of the rules of the road, 264 protocols were drawn up: 87 for pedestrians and three for car drivers driving a vehicle while intoxicated. Preventive measures were taken to prevent violations of the rules for trade and storage of goods subject to excise tax: 11 raids were carried out, resulting in 10 administrative protocols [3].

According to the draft law, one monetary unit will be five euros; it has also been established that the minimum fine for individuals and legal entities is two monetary units, and the maximum fine for individuals is 400 fine units, and legal entities -4000 fine units. These changes are necessary to improve the current code.

Article 28 regulates the confiscation of the subject of the item of an administrative offense. The confiscation of the subject of the item of committing an administrative offense means its compulsory free transfer to the ownership of the state.

According to statistics, from February 11 to 17, 2018 in Rezekne district, preventive measures were taken to prevent violations of the rules for trade and storage of goods subject to excise tax: two raids were carried out, resulting in two administrative proceedings [3].

It is obvious that currently this Article ( 28 of the $\mathrm{LAoC}$ ) is not effective in practice, due to the convention on the protection of human rights and fundamental freedoms, as well as the principles spelled out in Chapter 8 of the Constitution, which is why this issue was reflected in the draft law $[1,8]$.

An important form of punishment is administrative arrest (Article 31 of the LAoC). Discussion of the issue of refusal of administrative arrest and possible alternative options was initially discussed at international seminar in the Saeima, on September 30, 2013. 
Then the Ministry of Justice of the Republic of Latvia suggested a draft law in the international seminar in the Saeima providing for substantial reforms in the area of administrative violations, including the exclusion of administrative arrest as a form of punishment from the system of administrative sanctions [4].

The Speaker of the Saeima stressed: "The current system is not only expensive for the state, but it also has too little role in identifying and preventing the causes of violations that were found in other countries".

The discussion "Refusal from administrative arrest", initiated in the Saeima, was motivated by the theoretical foundations of the Institute for Administrative Arrest in Latvia, as well as by administrative arrest in international law and the practice of the European Court of Human Rights [5].

Building on this substantive draft law, the Chairman of the Saeima announced that the refusal of an administrative arrest is a logical step towards a more efficient system of administrative sanctions.

A number of fundamental changes are also reflected in the fact that legal norms will be regulated in a single legislation. These changes are taken into account to simplify the code, namely the statement of legal norms in a single legislation [7].

For example, if a person wishes to engage in fishing, all national requirements that apply to a person, as well as responsibility for non-compliance with these requirements, will be stated in a single legislation, in this case the Fisheries Act (Zvejniecibas likums) and the relevant regulations by the Cabinet of Ministers. The rules established in the Fisheries Act do not regulate liability for the commission of offenses. Those penalties that are regulated by the LAoC will be transferred to the above legislation, for simplicity and efficiency.

The codification of offenses in sectorial legislation, allows within the sector in a single legislation to find both prohibitions and penalties.

With the adoption of the new code, there has been its inclination to the European legal system. It is observed, and this is what contributed to the decision not to include administrative arrest, confiscation of the subject of an item, as a form of penalty in the new code.

These changes are taken into account by the legislator referring to the Convention for the Protection of Human Rights and Fundamental Freedoms.

\section{Conclusion}

It is advisable to make the following suggestions:

In the next edition, amend in part 1 of Article 26 of LAoC - "the minimum fine for individuals and legal entities is two monetary units, and the maximum fine for individuals is 400 fine units, and legal entities - 4000 fine units";

Exclude administrative arrest. Omit it from the new code. Usage of administrative arrests is inconsistent with human rights standards, and deprivation of liberty is provided 
only for criminal offenses. It is necessary to deal with this problem with an emphasis on preventive measures. In this case, it would be more expedient to take two main types of collection, a warning and a fine. Also, administrative arrest is an expensive punishment, since those arrested must be provided with food, medical assistance and approved conditions of detention;

Exclude the confiscation of the subject of the item of committing an administrative offense. This has been suggested since a simplified approach to the provided evidence of the guilty in the administrative offenses committed by one leads to a reduction in the quality institutions that have control over that work;

Regulate legal norms in a single legislation. This change will contribute to a clear, fast and efficient work of institutions. The codified offenses to sectorial legislation will make it easier to find, as a statement of those or other legal actions, and the sanction in the event of an offense. Especially, transfer the chapters 8, 9, 11, 12, 14, from the current code, which are sectorial. To simplify the code, the statement of legal norms in single legislations is taken into account.

\section{Galvenie administratīvo sodu veidi Latvijas Republikā}

\section{Kopsavilkums}

Šì raksta mērḳis ir identificēt problēmas Latvijas Republikas administratīvo sodu sistēmā. Darbā analizētas izmaiṇas Latvijas Administratīvo pārkāpumu kodeksā. Šĩ raksta sagatavošanā ir izmantota juridiskā literatūra, Eiropas un nacionālie tiesību akti.

Atslēgvārdi: izmaiṇas, sodi, pārkāpums, Latvijas Administratīvo pārkāpumu kodekss.

\section{References}

1. Latvijas Republikas konstitūcija (Eng. Constitution of the Republic of Latvia). Law of 15.02.1922 // Latvijas Vēstnesis, 104 (5676), 31.05.2016. In effect as of 07.11.1922.

2. Latvijas administratīvo pārkapumu kodekss (Eng. Latvian Administrative Offenses Code). Law of 07.12.1984. // Zinotājs, 51, 20.12.1984. In effect as of 01.07.1985.

3. Аатгация: полицейская статистика за неделю (Eng. Latgale: Police Statistics of the week // www.grani.lv/latvia/11884-latgaliya-policeyskaya-statistika-za-nedelyu.html (11.10.2018.).

4. Ministry of Justice of the Republic of Latvia. Likumprojekts par atteikšanos no administrativā aresta (Eng. The Draft Law on the Rejection of Administrative Arrest) // www.tm.gov.lv/lv/ aktualitates/tm-informacija-presei/saeima-starptautiska-seminara-diskute-par-atteiksanosno-administrativa-aresta-un-ta-alternativam (11.10.2018.). 
5. Ministry of Justice of the Republic of Latvia. Likumprojekts par atteikšanos no administratīvā aresta (Eng. The draft law on the rejection of administrative arrest) // www.saeima.lv (11.10.2018.).

6. Pārskats par nepilngadīgo noziedzības stāvokli, noziedzīgos nodarījumos cietušajiem bērniem un noziedzības novēršanas problēmām 2017.gada 12 mēnešos (Eng. State Police Review on the Status of Juvenile Delinquency, Children Victims of Crime and Crime Prevention Issues in the 12 Months of 2017 // www.vp.gov.lv/?id=305 (11.10.2018.).

7. The draft law on the creation of a new administrative code of Latvia // www.lvportals.lv/visi/ likumi prakse?id=290817 (08.10.2018.)

8. The European Convention for the protection of human rights and fundamental freedoms // www.echr.coe.int/Documents/Convention_ENG.pdf, 11.03.18. (08.10.2018.)

9. Cane, P. Administrative law. $4^{\text {th }}$ ed. Published in the United States by Oxford University Press Inc. New York, 2004.

10. Briede, J., Danovskis, E., Kovalevska, A. Administratīvās tiesības. Mācību grāmata. (Eng. Administrative Rights. Coursebook.) Tiesu namu aǵentūra. Rīga, 2016.

11. Načisčionis, J. Administratīvās tiesības: monogrāfija. (Eng. Administrative Rights: Monograph) Rīga: Biznesa augstskola Turība, 2018.

12. Stucka, A. Administratīvās tiesības. (Eng. Administrative Rights) Rīga: Juridiskā koledža, 2006.

13. Vildbergs, H. J., Krasts, V. Salīdzinošās administratīvās tiesības: lietas un risinājumi. Mācību lïdzeklis. (Eng. Comparative Administrative Rights: Cases and Solutions. Coursebook) 2. pārstr. un papild. izd. Rīga: Latvijas Universitāte, 2002. $2^{\text {nd }}$ revised and supplemented edition. 